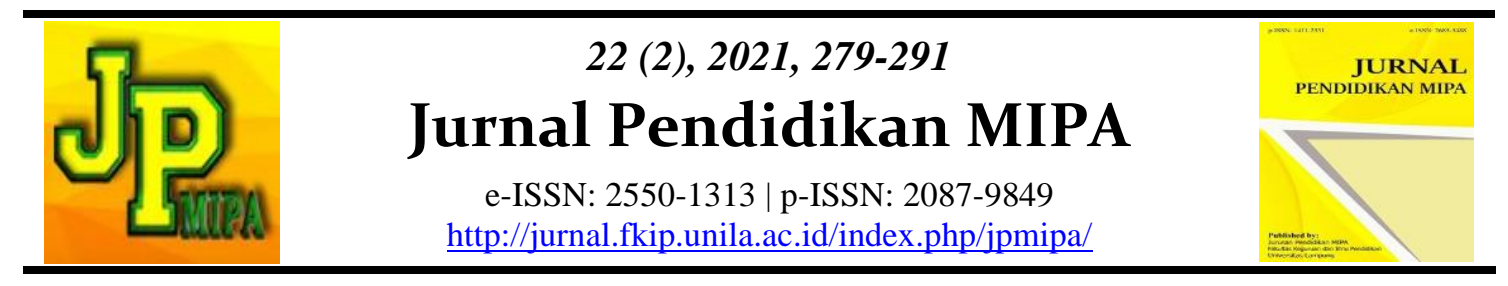

\title{
Development of Android-Based Interactive Learning Media on Listening, Imitating, and Reciting Materials for PAUD Students
}

\author{
Novi Hendri Adi ${ }^{*}$, Okta Veza ${ }^{1}$, Wakhinuddin Simatupang ${ }^{2}$, Dedy $\operatorname{Irfan}^{2}$, Mukhlidi Muskhir ${ }^{2}$, \\ Afif Rahman Riyanda ${ }^{3}$, Della Daphiza ${ }^{1}$ \\ ${ }^{1}$ Informatics Engineering, Universitas Ibu Sina, Indonesia \\ ${ }^{2}$ Technology and Vocational Education, Universitas Negeri Padang, Indonesia \\ ${ }^{3}$ Department of Information Technology Education, Universitas Lampung, Indonesia
}

\begin{abstract}
At the Al-Qur'an-based PAUDQ An Najah, they are required to innovate in learning activities during the pandemic. The learning media used in PAUDQ An Najah still uses paper media, so teachers have difficulty providing material during the pandemic. Researchers feel the need to develop android-based interactive learning media to improve the quality of learning during the Covid19 pandemic. The purpose of this study is to develop interactive learning media for the introduction of android-based Arabic vocabulary to assist teachers in the teaching process and to assist the role of parents in providing learning guidance to their children. The method used is Multimedia Development Life Cycle (MDLC), which has concept, design, material collecting, assembly, testing and distribution stages. This research produces interactive learning media applications that can be operated on parents' smartphones to support online learning. The conclusion of this study is that android-based interactive learning media is feasible to be applied to PAUDQ An Najah.
\end{abstract}

Keywords: Interactive Learning Media, MDLC, Android, PAUD

Abstrak: Pada PAUDQ An Najah yang berbasiskan Al-Qur'an dituntut untuk berinovasi dalam kegiatan belajar pada masa pandemic. Media pembelajaran yang digunakan pada PAUDQ An Najah masih menggunakan media kertas, sehinga guru kesulitan memberikan materi pada masa pandemic. Peneliti merasa perlu mengembangkan media pembelajaran interaktif berbasis android untuk meningkatkan kualitas belajar selama masa pandemi Covid19. Tujuan penelitian ini mengembangkan media pembelajaran interaktif pengenalan kosa kata bahasa arab berbasis android guna membantu guru dalam proses mengajar serta membantu peranan orang tua dalam memberikan bimbingan belajar kepada anaknya. Metode yang digunakan Multimedia Development Life Cycle (MDLC), memiliki tahapan concept, design, material collecting, assembly, testing dan distribution. Penelitian ini menghasilakan aplikasi media pembelajaran interaktif yang dapat operasikan pada smartphone orang tua untuk mendukung pembelajaran daring. Kesimpulan dari penelitian ini media pembelajaran interaktif berbasis android layak untuk diterapkan pada PAUDQ An Najah.

Kata kunci: Media Pembelajaran Interaktif, MDLC, Android, PAUD.

Novi Hendri Adi et al.

Email: novi.hendriadi@gmail.com
DOI: http://dx.doi.org/10.23960/jpmipa/v22i2.pp279-291

Received: 21 November 2021

Accepted: 25 December 2021 


\section{- INTRODUCTION}

The world of education in Indonesia is currently adjusting to technological developments. Characterized by improvements in the quality and quantity of education that never stops. These efforts are carried out to adjust and balance the development of world technology which accelerates very quickly both in the development of learning, learning innovation, and the fulfillment of educational facilities and infrastructure. The education system is developed in accordance with the needs and developments that occur, both locally, nationally and globally. Early childhood education is the most basic education as forming the characteristics of children. Early age is the most basic early period during the growth and development range of children. Children at an early age is the most appropriate time to instill values in children for intellectual, social, emotional, language, norms, and religious development. Early age is a golden age where this stage is effective in providing an element of goodness so that it is embedded in children from an early age (Islamiah, Fridani, \& Supena, 2019).

The world of education is currently getting a very valuable experience, the education process is usually centered in schools, with the Covid-19 social distancing, the learning process has finally moved to learning at home based on an internet connection, where face-to-face learning has to switch to in-person learning. network (online). The learning process in the midst of the Covid-19 pandemic, at least the student learning will be accompanied by parents. This condition due to Covid-19 provides an opportunity for parents to build closeness and be directly involved in their children's learning at home (Kartika, Erik Aditya Ismaya, \& Muhammad Noor Ahsin, 2021; Masrul, Leon A. Abdillah, 2020)(Sahir, Ramadhana, Marpaung, Munthe, \& Watrianthos, 2021).

An Najah PAUDQ School is an educational program equivalent to Al-Qur'an-based PAUD which was established in 2013 located in the Riau Islands Province, Batam City, Lubuk Baja District, Tanjung Uma Village, Jalan Hj. Samsinar No 11. PAUDQ An Najah is under the guidance of the Ministry of Religion and the auspices of the Darun Najah Al Harist Foundation which was established in 2010 with Registration Number: 411227.1.11/0003/072011. From the results of interviews with Mrs. Novia Andriana, AmKeb as the Principal of PAUDQ An Najah. During the covid19 pandemic, PAUDQ AN Najah carried out online teaching and learning activities using zoom media and video calls via wa. The obstacles faced by teachers when learning online started from internet quotas, signals, and also the moody condition of children, so that some of the material delivered could be conveyed well and some material was not conveyed properly. Some of these obstacles make the teaching and learning process not optimal. In the teaching and learning process PAUDQ An Najah has a learning curriculum B (Age 5-6 years) with competencies in Listening, Imitating, Reciting, Reading Hijaiyah Letters and Arabic numerals, memorizing short Surahs, Knowing Thoyyibah sentences, Knowing Asmaul Husna and Daily Prayers. This curriculum is in accordance with the decision of the director general of Islamic education regarding the national curriculum of Al-Quran education no 6091 of 2020 (Diniyah, Jenderal, Islam, \& Pendidikan, 2018).

Researchers conducted an initial survey by distributing a questionnaire instrument to parents to measure the effectiveness of online learning implemented by PAUDQ An Najah. The results of respondents' answers regarding the effectiveness of online learning are 24 guardians of students assessing it as ineffective with a percentage of $77.4 \%$ of the score, and 7 guardians of students assessing it as effective with a percentage of $22.6 \%$. Based on this data, of course, it is still relatively low in the level of effectiveness of online learning that is applied, so it is necessary to increase the effectiveness of learning during 
the pandemic. Therefore, every school institution, especially PAUDQ An Najah, is required to innovate in teaching and learning activities without making face-to-face meetings with students. To support the smooth learning process during the pandemic (Hendri Adi, Fernandes, \& Hermansyah, 2020)(Yanto, 2019). One of the innovations that can be applied to online learning is the use of learning media (Laila, Hb, \& Irsadi, 2016). The use of learning media can increase the motivation and interest of students if the media used can provide stimulation to students in the learning process (Candra, Elfizon, Islami, \& Yanto, 2020; Hutabri \& Putri, 2019; Zaus, Wulansari, Islami, \& Pernanda, 2018). Multimedia is defined as a computer program consisting of text, graphics, sound and images and animation. Interactive multimedia has different tools for connecting different pieces of software and interaction with users and giving them feedback is among other properties of multimedia. These characteristics enable users to advance, interact, create, and establish relationships with the software. Various types of media with various designs are combined with each other to help achieve learning objectives. Interactive multimedia is used in a learning environment so that it can help users increase their understanding, knowledge and confidence and encourage them to use multimedia in teaching and learning situations (Andreani \& Ying, 2019; Hamidi, Kharamideh, \& Ghorbandordinejad, 2011; Tuma, Malgor, \& Nassar, 2021).

The use of technology during this pandemic can be utilized by teachers and parents in online learning, one of which is by applying Android-based learning media. According to (Driyani, 2018) android is a software (software) used on mobile devices (running devices) which includes an operating system, middleware and core applications. This Android operating system is open source so that many programmers flock to make applications or modify this system. Android-based interactive learning media application was developed to help teachers in the learning process (Sari, Fadillah, Jonathan, \& Prabowo, 2019)(Yunus \& Sardiwan, 2018). Research (Ayuningtyas, Fadhilah, \& Arifin, 2018) with the title of learning media about animals in English based on interactive multimedia by producing interactive multimedia applications by visualizing the names of animals in English. Then research from (Aristo \& Hendra, 2020) with the title of designing learning media about endangered animals. The results of this study provide the attractiveness of animal learning media in the form of APK or android-based. Based on the problems above, therefore the authors are interested in making an application for developing Android-based interactive learning media on listening, imitating and reciting materials for PAUDQ students. The development of interactive learning media is expected to be able to increase motivation and provide stimulation to students towards learning.

\section{- METHOD}

This study uses a software development method used is the Multimedia Development Life Cycle (MDLC) method, which is a method of developing a multimedia system based on six stages, which consist of concept, design, material collecting, assembly, testing, and distribution (Mustika, Sugara, \& Pratiwi, 2018). Using the MDLC method the design process went smoothly because the method was clear and orderly (Setyabudi, Isnanto, \& Windasari, 2015). Stages of development in Multimedia Development Life Cycle (MDLC) that is: 


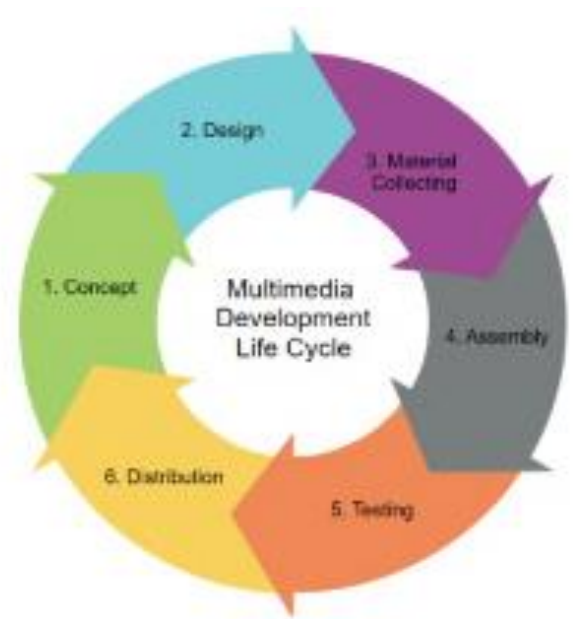

Figure 1. Method Stage MDLC

1. Concept

This stage is the earliest and most important stage. The concepts developed at this stage affect the whole of this research. Namely, the concepts, goals, and objectives of using Android-Based Interactive Learning Media

2. Design

At this stage, combine the concept and design of the storyboard in order to get a complete picture and understanding. At this stage, you will have to know how the final result of the visualization will be done

3. Material Collecting

In this stage is the collection of data and research materials that are appropriate to do. Among them are, learning materials from $B$

4. Assembly

At this stage is where all data objects will be created. Making this media is based on storyboards and narrations that have been made using the Adobe Flash CS6 application

5. Testing

The next stage is the testing stage of a media that has been completed. By running the application or program it can be seen whether there are errors or not, testing is carried out using the black box test. After the black box test, the researchers also conducted a feasibility test on the learning media that had been designed. Testing is done by distributing questionnaires to parents of students and teachers who use learning media. The measurement instrument used is a Likert scale with a description of the score of each item (Sugiyono, 2017).

Table 1. Scoring Scale

\begin{tabular}{llc}
\hline No & \multicolumn{1}{c}{ Category } & Range \\
\hline 1 & Very Worthy & $81-100$ \\
\hline 2 & Worthy & $61-80$ \\
\hline 3 & Decent enough & $41-60$ \\
\hline 4 & Not feasible & $21-40$ \\
\hline 5 & Very Inappropriate & $<20$ \\
\hline
\end{tabular}




\section{Distribution}

At this last stage, the Learning Media will be converted into APK format to be installed on mobile phones in Application demo mode.

\section{- RESULT AND DISCUSSION}

Making interactive learning media using the implementation of the stages of the MDLC method which consists of 6 (six) stages, namely concept, design, material collecting, assembly, testing, and distribution as follows:

1. Concept

At this stage, the formulation of the concept is produced the purpose of the application is an interactive multimedia-based learning media designing Android-based learning media at PAUDQ An Najah Batam. The benefits of learning media to facilitate learning at home. The use of learning media is PAUDQ An Najah students with the guidance of their respective parents. Description of Android-Based Interactive Learning Media can be operated on computers and smartphones

2. Design

At this stage the Design process is combined in order to get a complete picture and understanding, following the design process formed in the first stage is the animation design process starting from the storyboard.

Table 2. Storyboard

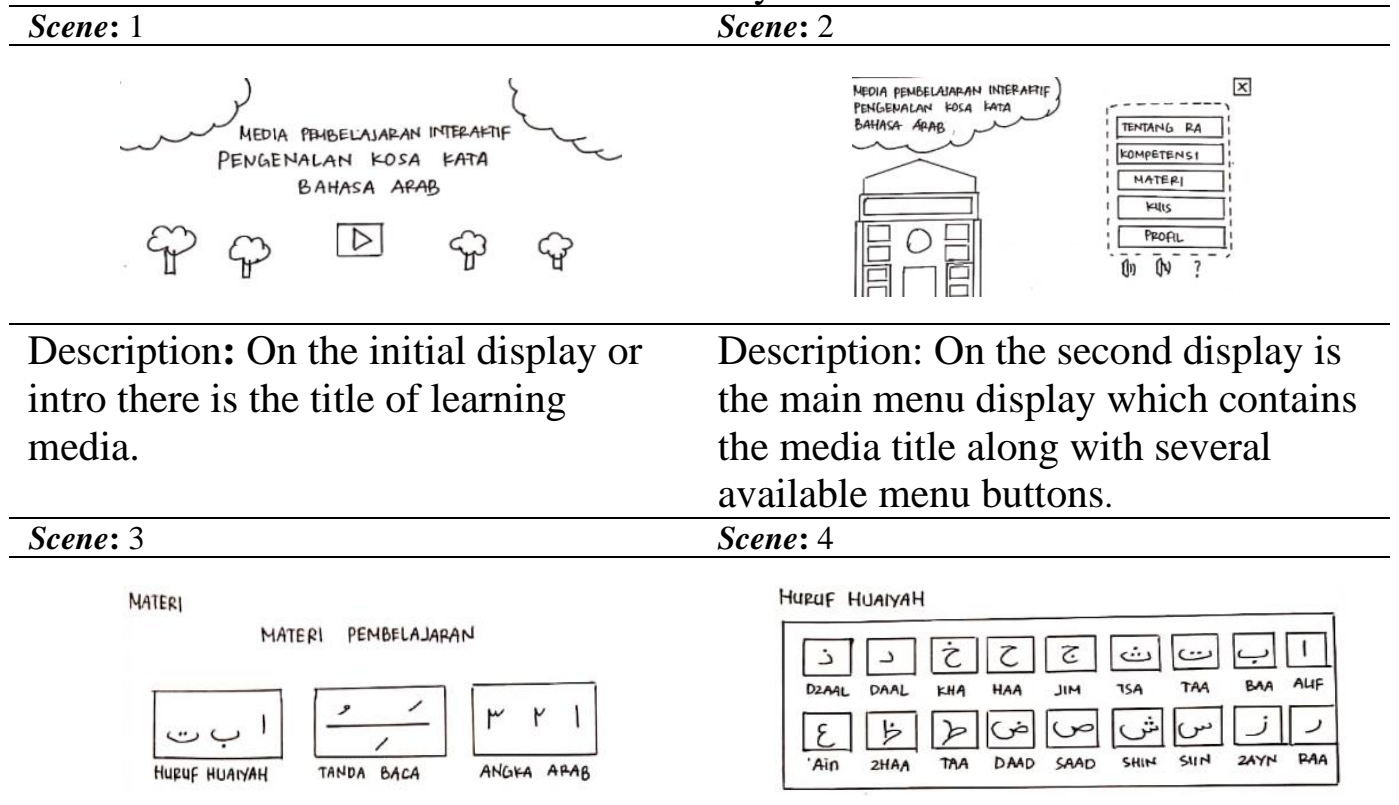

\begin{tabular}{ll}
$\begin{array}{l}\text { Deskripsi: In this display is a display } \\
\text { of learning material that contains three }\end{array}$ & $\begin{array}{l}\text { Description: the display of the hijaiyah } \\
\text { letter material contains } 30 \text { hijaiyah }\end{array}$ \\
$\begin{array}{l}\text { punctuation mamely hijaiyah letters, } \\
\text { numbers. }\end{array}$ & letters. \\
\hline Scene: 5 & Scene: 6 \\
\hline
\end{tabular}


TANDA BACA

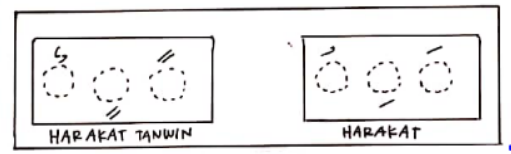

ANGKA ARAB

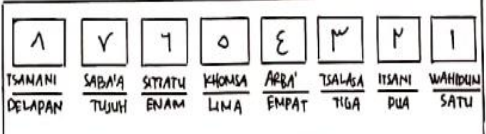

\begin{tabular}{ll}
\hline $\begin{array}{l}\text { Description: Displays punctuation } \\
\text { material, namely Harakat and Harakat }\end{array}$ & $\begin{array}{l}\text { Description: The tenth display is a } \\
\text { material display of Arabic numerals } \\
\text { fanwin. }\end{array}$ \\
\hline Scene: 7 & Scene: 8 \\
\hline
\end{tabular}

Description: Displays the quiz menu, Description:. Showing a guide for there are three materials for each quiz question and a total of 10 questions for each material

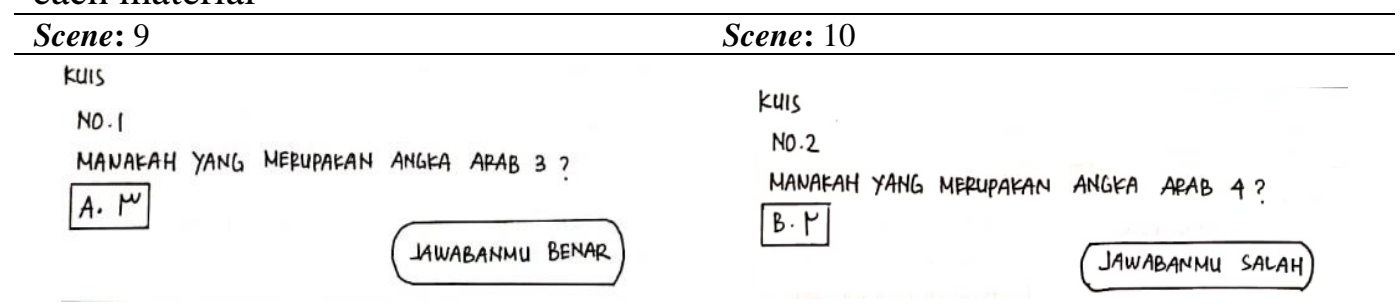

\section{Description: Displays quiz answers if Description: Displays the quiz answered correctly. answer if the answer is wrong.}

\section{Material Collecting}

At this stage as well as the collection of results in accordance with the needs carried out for these materials, including pictures clipart animated photos and more.

Table 3. Material Collecting

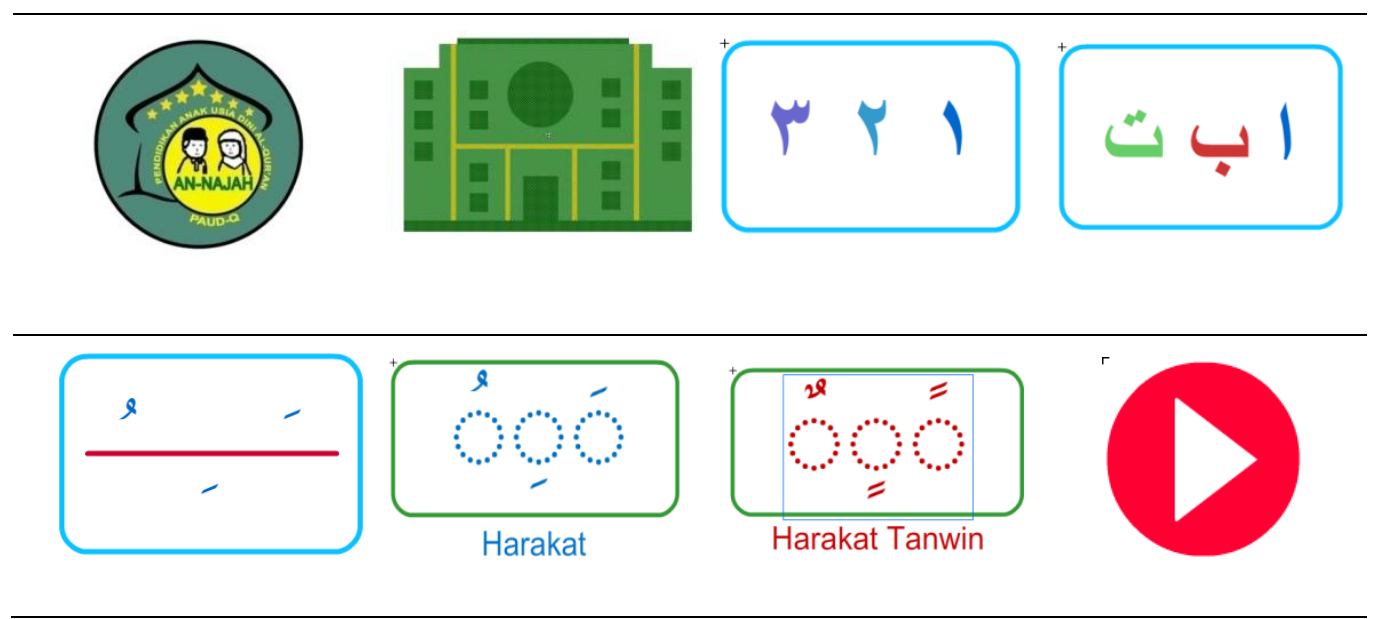




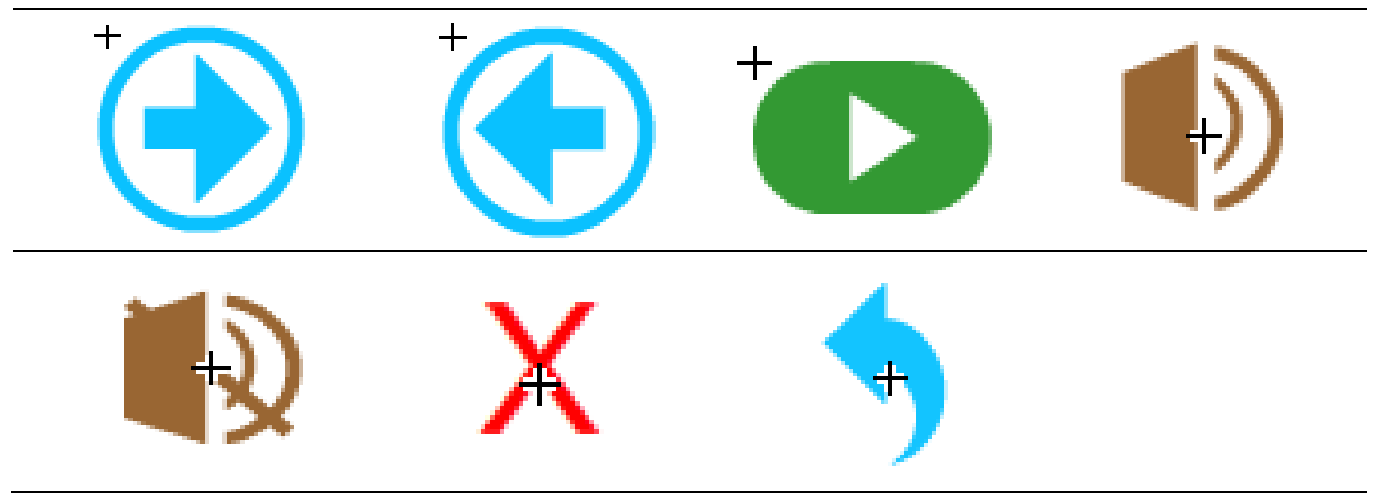

\section{Assembly}

This stage is where all multimedia objects will be created. Making this media based on the storyboard that has been made. The software used to create this two-dimensional animation is Adobe Flash cs6

a. Animation Making

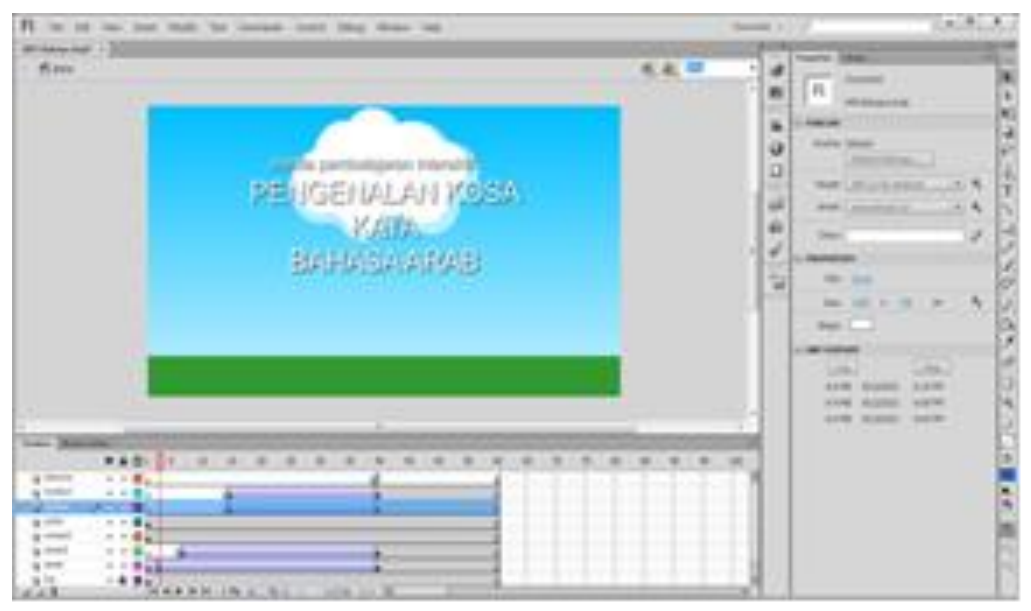

Figure 1. Intro View

Where on the initial display is the intro display to start entering learning media there is an interactive learning media title and a start button.

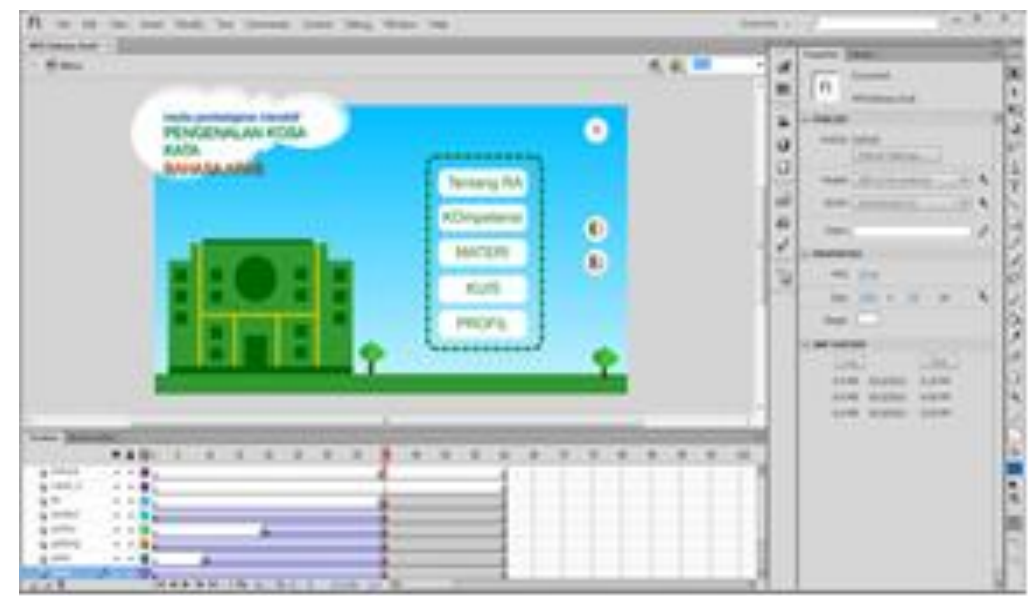

Figure 2. Main Menu Display 
Opening process Learning media displays opening writing using keyframe effects and writing using Times new roman characters displaying the PAUDQ An Najah Batam logo, using children's sounds.

b. Implementation Results

At this stage it is the result of the implementation of an Android-based interactive learning media application that has been installed on a smartphone. The following is a display of interactive learning media that has been installed on an Android smartphone.

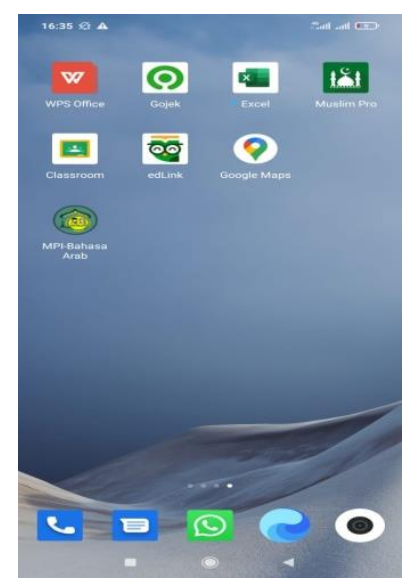

Figure 3. Learning Media Application

In this view, is the initial display that appears when learning media on Android is run on a smartphone. This display contains the title of interactive learning media with the introduction of Arabic vocabulary and has a play button to start running the android application.

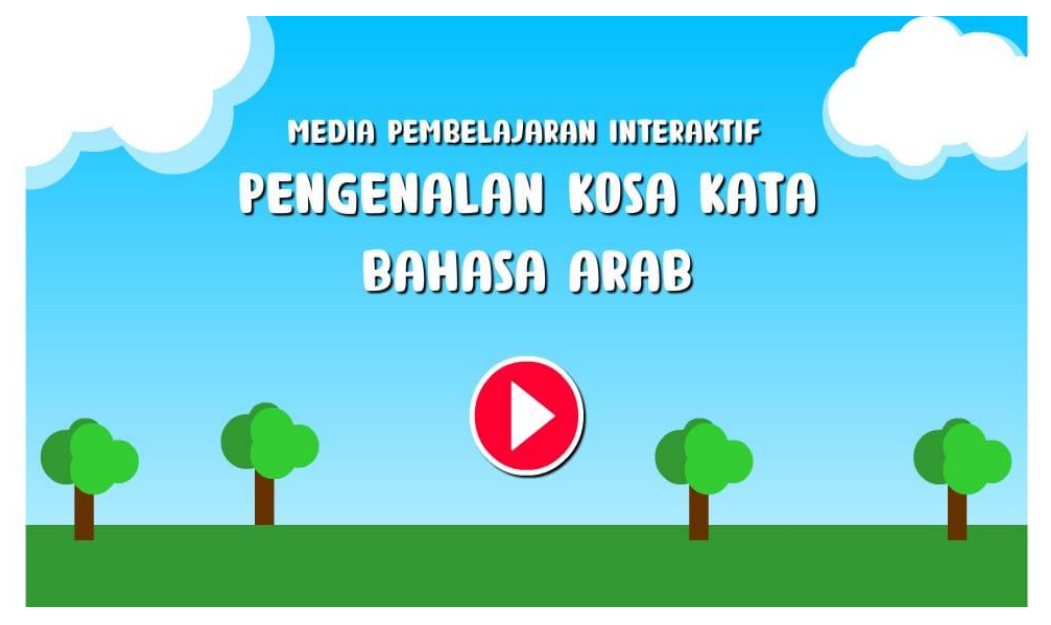

Figure 4. Initial Display of Android-based Learning Media

This display contains a menu of learning materials that have three material buttons, namely hijaiyah letters, punctuation marks and Arabic numbers. 


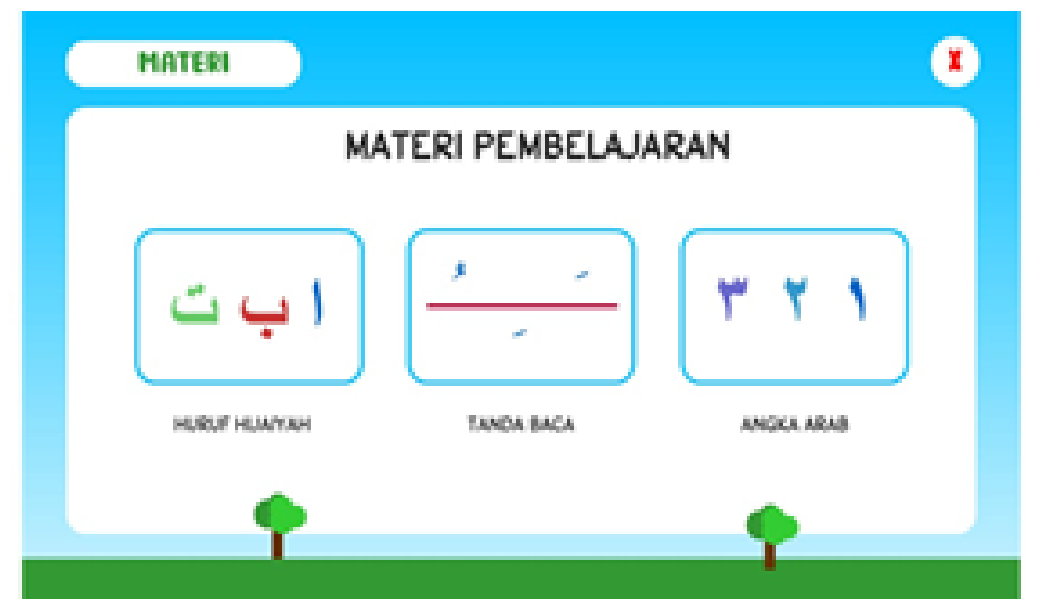

Figure 5. Learning Material Menu Display

The display of the Arabic numeral material menu contains numbers 1-20 letters and there are pictures, readings and sounds of each hijaiyah letter button when clicked.

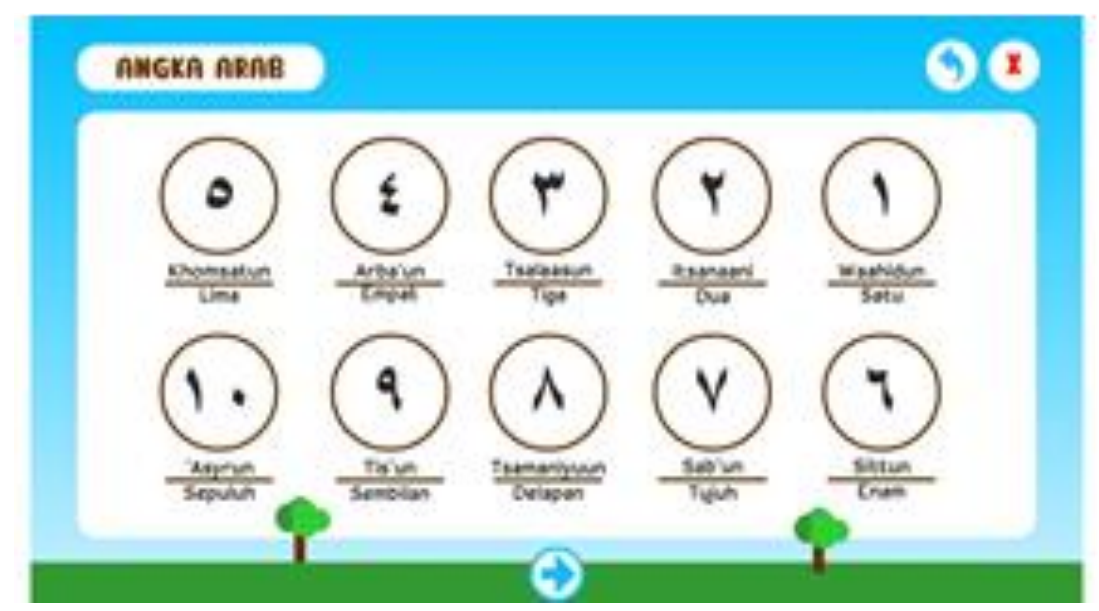

Figure 6. Display Menu Material Arabic Numerals

\section{Testing}

The testing stage is carried out after the assembly stage is complete by running the application/program to see if there are errors or not. At this stage, testing is carried out using black box testing. Tests on devices with image indicators consisting of image testing, application background, image testing on application buttons, and testing on supporting images run according to their functions. The button indicator which consists of testing the material button, next button, quiz question button, and back button runs according to its function. On the animation and sound indicators which consist of testing on animation effects, the back sound from the media and the sound on the buttons work according to their function. After testing the learning media devices using the black box test, then further testing the feasibility of learning media for teachers who teach in curriculum B. The instrument used in this feasibility test is in the form of a questionnaire given to three teachers with ten questions. The following are the results of the assessment given by the teacher. 
Table 4. Teacher Assessment

\begin{tabular}{rlcl}
\hline No & \multicolumn{1}{c}{ Aspect } & Score & Category \\
\hline 1 & Convenience & 93 & very feasible \\
\hline 2 & Effectiveness & 87 & very feasible \\
\hline 3 & Design attractiveness & 90 & very feasible \\
\hline 4 & Material & 87 & very feasible \\
\hline 5 & Customize shape & 86 & very feasible \\
\hline 6 & Color & 88 & very feasible \\
\hline 7 & Voice & 90 & very feasible \\
\hline 8 & Material equipment & 86 & very feasible \\
\hline 9 & Material suitability & 86 & very feasible \\
\hline 10 & Student needs & 90 & very feasible \\
\hline & average & $\mathbf{8 8 . 3}$ & very feasible \\
\hline
\end{tabular}

Judging from the ten aspects with an assessment by three teachers, namely as follows: based on the ease of use of the media, the average score was 93\%. Based on the aspect of effectiveness obtained an average value of $87 \%$. Based on the attractiveness aspect of the interface design, the average score is $90 \%$. Based on the material aspect, the average score is $87 \%$. Based on the aspect of the suitability of the form and typeface, the average score is $86 \%$. Based on the colour aspect, the average value is $88 \%$. Based on the background sound aspect, the average value is $90 \%$. Based on the aspect of completeness of the material obtained an average score of $86 \%$. Based on the aspect of material suitability, the average score was $86 \%$. Based on the aspect of student needs, an average score of $90 \%$ was obtained. The total average percentage of all aspects obtained from the three teachers was $88,3 \%$. It can be concluded that the learning media in the form of applications Arabic vocabulary recognition is in the very feasible category to use.

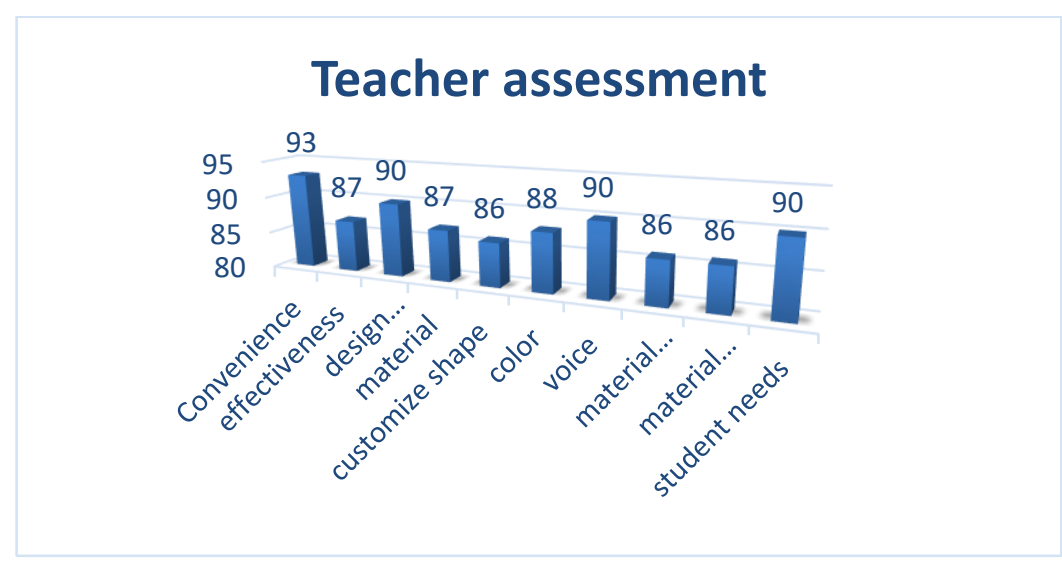

Figure 7. Teacher Rating Percentage

After the feasibility test was carried out on the teacher, then a behavior test was also carried out to the parents of students on the interactive learning media whether it was feasible to use or not. 


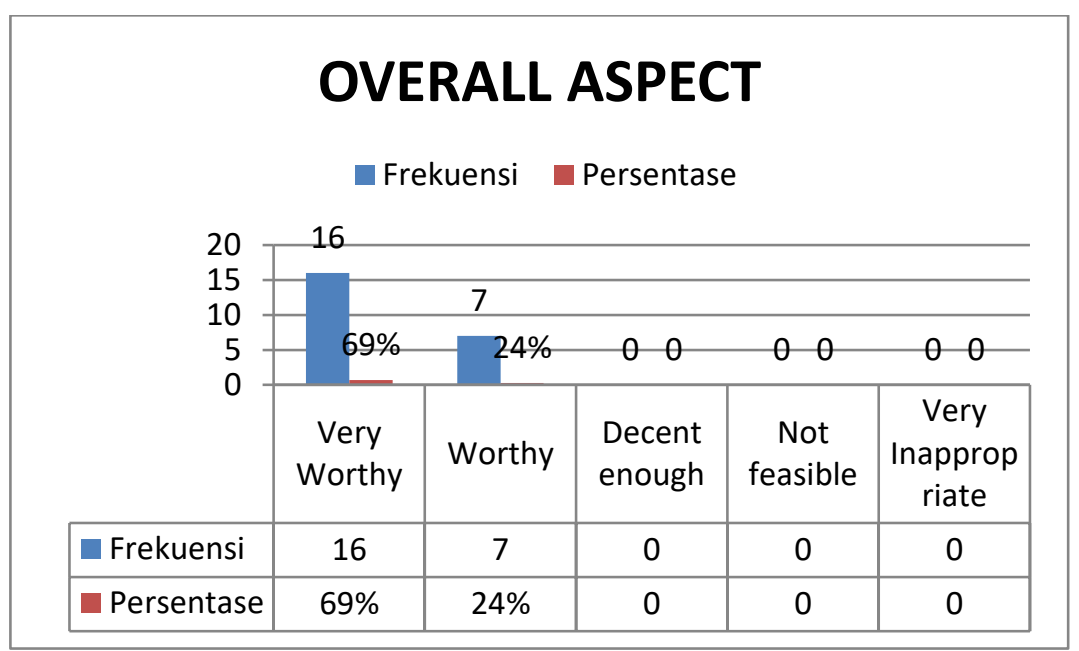

Figure 8. Percentage of Assessment of Respondents or Guardians of Students

It can be concluded from the summary of the percentage of five questions obtained an overall assessment by 23 guardians of students assessing $69 \%$ in the very appropriate category and $24 \%$ in the appropriate category.

\section{Distribution}

At this stage, the APK that has been converted from Adobe Flash cs6 will be stored on the Android of the parents or guardians of PAUDQ An Najah Batam students. The distribution stage is also the stage where the evaluation of a multimedia product is carried out. By doing an evaluation, it will be able to develop a better one in the future.

\section{- CONCLUSION}

Based on the results of research and discussion on the Design of Interactive Learning Media with Competency Curriculum B at PAUDQ An Najah Based on Android, it can be concluded several things as follows Interactive learning media is designed using the MDLC method. Consists of six stages, namely: concept (conception), design (design), collecting material (material collection), assembly (manufacture), testing (testing), and distribution (distribution). The results of the design research conducted through the testing phase by 3 PAUDQ Teachers An Najah found that interactive learning media was declared feasible. The feasibility of interactive learning media is seen from the results of the assessment by 3 teachers. Based on this assessment, it was obtained an overall average score of $93 \%$ which was included in the very feasible category. The results of the research on the design of interactive learning media which were carried out through the assessment stage by 23 PAUDQ An Najah guardians found that interactive learning media were declared

\section{- REFERENCES}

Andreani, W., \& Ying, Y. (2019). "PowPow" interactive game in supporting English vocabulary learning for elementary students. Procedia Computer Science, 157, 473-478. https://doi.org/10.1016/j.procs.2019.09.005

Aristo, C., \& Hendra, Y. (2020). Perancangan Media Pembelajaran Tentang Hewan yang Terancam Punah. 01(02), 1-14. Retrieved from http://repository.uib.ac.id/id/eprint/1940

Ayuningtyas, I., Fadhilah, M. A., \& Arifin, R. W. (2018). Media Pembelajaran Mengenal 
Hewan Dalam Bahasa Inggris Berbasis Multimedia Interaktif. PIKSEL : Penelitian Ilmu Komputer Sistem Embedded and Logic, 6(1), 85-94. https://doi.org/10.33558/piksel.v6i1.1403

Candra, O., Elfizon, E., Islami, S., \& Yanto, D. T. P. (2020). Penerapan Multimedia Interaktif Power Point Pada Mata Diklat Dasar Dan Pengukuran Listrik. CIRCUIT: Jurnal Ilmiah Pendidikan Teknik Elektro, 4(2), 87. https://doi.org/10.22373/crc.v4i2.6660

Diniyah, D. P., Jenderal, S. D., Islam, P., \& Pendidikan, K. (2018). Direktur Pendidikan Diniyah dan Pondok Pesantren Sekretaris Direktorat Jenderal Pendidikan Islam.

Driyani, D. (2018). Perancangan Media Pembelajaran Sekolah Dasar Berbasis Android Menggunakan Metode Rekayasa Perangkat Lunak Air Terjun ( Waterfall ). STRING (Satuan Tulisan Riset Dan Inovasi Teknologi), 3(1), 35. https://doi.org/10.30998/string.v3i1.2725

Hamidi, F., Kharamideh, Z. M., \& Ghorbandordinejad, F. (2011). Comparison of the training effects of interactive multimedia (CDs) and non-interactive media (films) on increasing learning speed, accuracy and memorization in biological science course. Procedia Computer Science, 3, 144-148. https://doi.org/10.1016/j.procs.2010.12.025

Hendri Adi, N., Fernandes, A. L., \& Hermansyah, H. (2020). Pengembangan Media Pembelajaran Berbasis Android Pada Mata Kuliah Fisika Dasar. Cetta: Jurnal Ilmu Pendidikan, 3(1), 103-114. https://doi.org/10.37329/cetta.v3i1.414

Hutabri, E., \& Putri, A. D. (2019). Perancangan Media Pembelajaran Interaktif Berbasis Android Pada Mata Pelajaran Ilmu Pengetahuan Sosial Untuk Anak Sekolah Dasar. Jurnal Sustainable: Jurnal Hasil Penelitian Dan Industri Terapan, 8(2), 57-64. https://doi.org/10.31629/sustainable.v8i2.1575

Islamiah, F., Fridani, L., \& Supena, A. (2019). Konsep Pendidikan Hafidz Qur'an pada Anak Usia Dini. Jurnal Obsesi : Jurnal Pendidikan Anak Usia Dini, 3(1), 30. https://doi.org/10.31004/obsesi.v3i1.132

Kartika, M., Erik Aditya Ismaya, \& Muhammad Noor Ahsin. (2021). Analisis Pembelajaran Daring di SD 2 Tenggeles Mejobo Kudus pada Masa Pandemi Covid19. Lectura: Jurnal Pendidikan, 12(1), 41-56. https://doi.org/10.31849/lectura.v12i1.5906

Laila, K. N., Hb, F. P. M., \& Irsadi, A. (2016). Efektifitas Media Pembelajaran Androplantae Berbasis Android Pada Materi Dunia Tumbuhan Untuk Siswa Sma. Journal of Biology Education, 5(2), 110-115. https://doi.org/10.15294/jbe.v5i2.14651

Masrul, Leon A. Abdillah, N. (2020). Social Distancing dan Budaya Kita. Pandemik COVID-19 Persoalan Dan Refleksi, (May), 39-47. Retrieved from https://www.researchgate.net/publication/341218892

Mustika, M., Sugara, E. P. A., \& Pratiwi, M. (2018). Pengembangan Media Pembelajaran Interaktif dengan Menggunakan Metode Multimedia Development Life Cycle. Jurnal Online Informatika, 2(2), 121. https://doi.org/10.15575/join.v2i2.139

Sahir, S. H., Ramadhana, R. S. A., Marpaung, M. F. R., Munthe, S. R., \& Watrianthos, R. (2021). Online learning sentiment analysis during the covid-19 Indonesia pandemic using twitter data. IOP Conference Series: Materials Science and Engineering, 1156(1), 12011.

Sari, A. C., Fadillah, A. M., Jonathan, J., \& Prabowo, M. R. D. (2019). Interactive gamification learning media application for blind children using android 
smartphone in Indonesia. Procedia Computer Science, 157, 589-595. https://doi.org/10.1016/j.procs.2019.09.018

Setyabudi, D. R., Isnanto, R. R., \& Windasari, I. P. (2015). Perancangan Aplikasi "Dunia Hewan" untuk Pembelajaran Anak Usia Dini Berbasis Android. Jurnal Teknologi Dan Sistem Komputer, 3(2), 213. https://doi.org/10.14710/jtsiskom.3.2.2015.213218

Sugyono. (2017). Metode Penelitian Kuantitatif, Kualitatif, dan R\&D. Bandung: Cv. Alfabeta.

Tuma, F., Malgor, R. D., \& Nassar, A. K. (2021). Actions to enhance interactive learning in surgery. Annals of Medicine and Surgery, 64(March), 102256. https://doi.org/10.1016/j.amsu.2021.102256

Yanto, D. T. P. (2019). Praktikalitas Media Pembelajaran Interaktif pada Proses Pembelajaran Rangkaian Listrik. INVOTEK: Jurnal Inovasi Vokasional Dan Teknologi, 19(1), 75-82. https://doi.org/10.24036/invotek.v19i1.409

Yunus, Y., \& Sardiwan, M. (2018). Perancangan dan Pembuatan Media Pembelajaran Berbasis Android pada Mata Pelajaran Sistem Komputer. Jurnal Pti (Pendidikan Dan Teknologi Informasi) Fakultas Keguruan Ilmu Pendidikan Universita Putra Indonesia "Yptk" Padang, 5(2), 31-41. https://doi.org/10.35134/jpti.v5i2.11

Zaus, M. A., Wulansari, R. E., Islami, S., \& Pernanda, D. (2018). Perancangan Media Pembelajaran Listrik Statis dan Dinamis Berbasis Android. INTECOMS: Journal of Information Technology and Computer Science, 1(1), 1-7. https://doi.org/10.31539/intecoms.v1i1.140 